\title{
Oxidative Stress and Haematological Response in Rainbow Trout (Oncorhynchus Mykiss) Fed With Brewer Yeast (Saccharomyces Cerevisiae) as Nutritional Supplement
}

\author{
CRISTIAN OVIDIU COROIAN ${ }^{1}$, VIOARA MIRESAN ${ }^{1}$, CAMELIA RADUCU ${ }^{1}$, CLAUDIA COSTEA ${ }^{1}$, RADU CONSTANTINESCU ${ }^{1}$, \\ AURELIA COROIAN ${ }^{1 *}$, MIHAI IACOB BENTEA ${ }^{1}$, DANIEL SIMEANU ${ }^{2}$, CRISTINA GABRIELA RADU-RUSU², CALIN LATIU ${ }^{1}$, \\ DANIEL COCAN ${ }^{1 *}$ \\ ${ }^{1}$ University of Agricultural Sciences and Veterinary Medicine Cluj-Napoca, 3-5 Manastur St., 400372 Cluj-Napoca, Romania \\ ${ }^{2}$ University of Agricultural Sciences and Veterinary Medicine Iasi, 3 Mihail Sadoveanu Alley, 700490 lasi, Romania
}

\begin{abstract}
Production of freshwater fish evolved constantly over the past decades in parallel with increasing the amount of ingredients conventionally used to feed these fish. From the main ingredients, those protein based are the most expensive and increasingly difficult to obtain. Fishmeal demands valuable alternative ingredients to replace it and yeasts seem to offer new protein sources, but not only, acting as probiotics in fish feed. We tested productive and physiological benefits of brewer yeast (Saccharomyces cerevisiae) added 1.5\% in standard rainbow trout (Oncorhynchus mykiss) nutrition with Coppens fodder (2 $\mathrm{mm}$ granulation) with $45 \%$ crude protein (CP) over a period of 45 days, starting at an average live weight of 56.86 gramsin a classical system of breeding. Production parameters as average daily gain (ADG), total live gain (TLG) and feed conversion rate (FCR) but also hematologic and biochemical blood parameters have been evaluated. Yeast fed batch presented higher productive indices but not statistically represented. Significant differences were observed in hematological parameters for hemoglobin, very significant response of yeast fed batch regarding gamma globulins (GGL) level and significant changes were also recorded for total proteins (TP). Significantly lower values for amylase were revealed, while enzymatic profile shown significant differences in alkaline phosphatase (PAL) and creatinine phosphokinase (CPK). Overall, 1.5\% of dried brewer yeast added to standard fodder in rainbow trout das led to a better use of feed and a strengthening of immunity.
\end{abstract}

Keywords: Oncorhynchus mykiss, Saccharomyces cerevisiae, hematology, serum biochemistry, oxidative stress

Rainbow trout (Oncorhynchus mykiss) is one of the most appreciated fish species of freshwater as fresh fish meat. Its nutrition in aquaculture systems is mainly based on concentrate fodder, with various protein and energy levels and forms of administration [1-3]. Multiple energy and protein levels have been tested in the past decades and now species nutrition is strongly documented and generally established [3, 4]. Among receipt ingredients used in fish nutrition in general, those protein based are by far the most expensive to procure. Although it seems that the best protein ingredient in fish nutrition is fishmeal, multiple causes such more and more limited resources [5-8] impose its replacement with other products with more or less similar productive effects. Among those, yeasts seem to successfully replace fish meal in several experiments on aquatic species [9-11]. Easy to produce and far away less expensive, yeasts offer high protein levels, e.g. the content of crude protein varies between $40 \%$ and $55 \%$ of the dry matter including contents of nucleic acids [12], and are rich in minerals suchphosphorus, calcium, sodium, zinc, iron, copper, manganese, and selenium [13]. Furthermore, yeasts such as Saccharomyces cerevisiae and Candida utilis are an important source of vitamins, predominantly B-vitamins, e.g. riboflavin, pyridoxine, niacin and pantothenic acid [12]. S. cerevisiae is easy to grown on low-cost media, can be easily manipulated, but most important its genome has been entirely sequenced and many cellular processes have been already identified [14]. Within nutritional aspects, yeasts such $S$. cerevisiae successfully replaced fishmeal in some fish species, e.g.

* email: coroian.aurelia@gmail.com; daniel.cocan@usamvcluj.ro
Gilthead sea bream (Sparus aurata) [15] or red claw crayfish (Cherax quadricarinatus) [16] based on protein digestibility level, but the opposite was revealed for some salmonid fish species such as rainbow trout (0. mykiss) [13], Atlantic salmon (Salmo salar L.) [17] and Arctic char (Salvelinus alpinus) [18]. Apart from protein digestibility, fermented $S$. cerevisiae supplementation in O. mykiss resulted in increased feed intake, followed by improved feed conversion ratio (FCR) and growth performance [19]. To the same species, functional diets based on pre- or probiotics dynamically modulate intestinal microbiota of juvenile rainbow trout to whose effects might impact fish physiological performance [20]. Beyond effectively replacing one ingredient with another, amino acid targets to be met based on ideal amino acid balance of trout muscle (0. mykiss) for Lysine, Methionine and Tryptophan seems to no longer create any differences due to the ingredients used, whether vegetal or animal origin [21].

Anyway, comparing with other vegetal resources usually replacing the fishmeal such is soybean meal, yeasts presents strong advantages among which technology process and not using land and water resources face it to be selected. Moreover, although soybean is a valuable replacement protein-based ingredient for fishmeal, it has anti-nutritional factors which can induces inflammation and oxidation, causes dysfunction of intestinal digestion and absorption in fish and depress fish grow th in Cyprinus carpio [22]. Casein replacement from fishmeal with extracted soybean meal (SBM) or soybeanprotein concentrate (SPC) has significantly depressed growth rate in rainbow trout, but has partially positive results in an 
omnivorous or frugivorous species pacu (Piaractus mesopotamicus) [23]. Apart of soybean, other vegetable protein sources showed success in replacing fishmeal, i.e. rapeseed and peas and maize gluten [24], soy flower [25] and other in rainbow trout, but also lupin meal or pea meal [26], barley [27] to Atlantic salmon.

Beyond nutritional aspects, probiotic role of yeasts must not be neglected. Yeasts species naturally populate fishes' gut [28] so direct feeding with one of the self-commensal organisms or the same genera appears as natural. Although various species or subspecies of yeasts relate commensalism with various fish species, multiple testing of such organisms as nutrients, prebiotics or for physiological studies gains more interest.

In spite of multiple advantages already shown in salmonid fish species, the overall literature is relatively scarce in physiological studies which imply yeasts in general, even little with $S$. cerevisiae - beer yeasts. In rainbow trout nutrition, yeasts such grain distiller's dried yeast (GDDY) have been successfully replaced the fishmeal, in various fractions from $15-18 \%$ [29] up to 25 $37.5 \%$ [30] with no alterations of growth rate or FCR.

We tested the physiological and productive effects of dried brewer yeast ( $S$. cerevisiae) added to granulated fodder in rainbow trout based on blood parameters, serum biochemistry and oxidative stress indicators enzymes activity, indicators which have proven their role in adaptive patterns [31] and fish health. In addition, feed conversion ratio (FCR) and rhythm of growth were evaluated.

\section{Experimental part}

\section{Material and methods}

Biological material and fodder

200 individuals of 0 . mykiss with an average live weight of 56.86 grams and organized in two plots with 100 individuals each were fed differentially with two specific granulated fodders during 45 days (March-April 2018). Both plots were fed to apparent satiation two times a day. Control plotreceived Coppens fodder ( $2 \mathrm{~mm}$ granulation) with $45 \%$ crude protein (CP) and 19.7 MJ metabolizable energy, while experimental plot received the same fodder plus $1.5 \%$ beer yeasts ( $S$. cerevisiae). The yeast has been incorporated into granulated fodder, the fishes receiving the same granulation fodder, with the same physical characteristics.

\section{Water and blood analyses}

The water parameters (temperature and $p H$ ) from the two tanks have been daily recorded with a multi-parameter Hanna HI - 9828 ensuring the same conditions for both plots. Average daily gain (ADG), total live gain (TLG) and feed conversion rate (FCR) were calculated as Halver and Hardy [3].

Blood samples from caudal veins were sampled from 10 individuals randomly selected from each plot in $3 \mathrm{~mL}$ blood sample tube with Litium-Heparin as anticoagulant at the end of the experiment.

Hematologic profile consisted in a set of analyses to determine: the number of erythrocytes $\left(\mathrm{RBC} \times 10^{6} / \mathrm{mm}^{3}\right)$, respectively the hematocrit (Hct-\%) and the hemoglobin level $(\mathrm{Hb}-\mathrm{g} / \mathrm{dL})$. Erythrocytes and hemoglobin analyses have been performed based on spectrophotometry techniques (UV-VIS Screen Master Touch). An End-Point colorimetric reaction and read in the NIS spectra range using $0.4 \%$ ammonium hydroxide $\mathrm{NH}_{4} \mathrm{OH}$ in distilled water as reagent was used for hemoglobin. A turbidimetriccolorimetric EP-type reaction with visible reading was used for erythrocytes using as a reagent an acetic solution of sodium sulfate $\mathrm{Na}_{2} \mathrm{SO}_{4}$ in distilled water (Gowens reagent).
Hematocrit was determined by direct centrifugation at $12,000 \mathrm{rpm} / \mathrm{min} / 3 \mathrm{~min}$. Erythrocyte index MCV was calculated based on the formulations set forth by Ghergariu $\&$ al [32]: Mean Corpuscular Volume MCV $=(H T \times 10) /$ RBC.

Blood biochemical analyzes were performed to determine the metabolic profile. Overall metabolic profile was subdivided into protein, lipid, carbohydrate, mineral and enzymatic profiles. The biochemical profiles were performed based on spectrophotometry techniques with specific wavelength $(\lambda)$ readings. For each of the profiles average values were recorded. The protein profile consisted in mean values for urea (BUN $-\mathrm{mg} / \mathrm{dL}, \lambda=340$ $\mathrm{nm}$ ), total protein (TP - g/dL, $\lambda=546 \mathrm{~nm}$ ), albumin (ALB $\mathrm{G} / \mathrm{dL}, \lambda=630 \mathrm{~nm}$ ) and gamma globulins ( $\mathrm{GGL}-\mathrm{G} / \mathrm{dL}, \lambda=$ $405 \mathrm{~nm}$ ). The lipid profile measured cholesterol (CHOL $\mathrm{mg} / \mathrm{dL}, \lambda=500 \mathrm{~nm})$, triglycerides $(\mathrm{TG}-\mathrm{mg} / \mathrm{dL}, \lambda=550$ $\mathrm{nm}$ ) and lipase (LIP - U/L, $\lambda=580 \mathrm{~nm}$ ). The carbohydrate profile measured glucose $(\mathrm{GLU}-\mathrm{mg} / \mathrm{dL}, \lambda=50 \mathrm{~nm})$ and amylase (AMS - U/L, $\lambda=620 \mathrm{~nm}$ ). The mineral measured values for calcium ( $\left.\mathrm{Ca}^{2+}-\mathrm{mg} / \mathrm{dL}, \lambda=575 \mathrm{~nm}\right)$, iron $\left(\mathrm{Fe}^{3+}\right.$ $-\mu \mathrm{g} / \mathrm{dL}, \lambda=630 \mathrm{~nm})$, phosphorus $(\mathrm{P}-\mathrm{mg} / \mathrm{dL}, \lambda=340 \mathrm{~nm})$ and sodium $(\mathrm{Na}-\mathrm{mmol} / \mathrm{L}, \lambda=405 \mathrm{~nm})$. The enzymatic profile measured the average values for creatinine (CREAT - $\mathrm{mg} / \mathrm{dL}, \lambda=520 \mathrm{~nm}$ ), alanine aminotransferase (ALAT $\mathrm{U} / \mathrm{L}$ ), aspartate aminotransferase (ASAT - U/L), glutamyl transferase (GGT - U/L), alkaline phosphatase (ALP - U/L, $\lambda=405 \mathrm{~nm})$, lactate dehydrogenase (LDH $-\mathrm{U} / \mathrm{L})$ and creatinine phosphokinase (CPK - U/L, $\lambda=340 \mathrm{~nm}$ ), respectively.

Another indicator of the physiological status and health status of living organisms, including fish, is oxidative stress. Antioxidant enzymes activity such are glutathione peroxidase (GPx, $\lambda=340 \mathrm{~nm})$, superoxide dismutase (SOD, $\lambda=505 \mathrm{~nm}$ ) has been evaluated. The values of these antioxidant enzymes give us physiological indications about the reactive oxygen species and implicitly about the health status of the fishes.

\section{Statistical analysis}

All raw data obtained was statistically interpreted, calculating average values, statistical based differences and dispersion indices using Graph Pad 6.0. A confident interval of $95 \%$ was set. A Mann Whitneyt-test was applied after a preliminary $F$ test for variance testing was performed.

\section{Results and discussions}

Experimental plot revealed higher ADG, TLG and FCR. In control group ADG was 0.452 grams/day while in yeast fed group was $0.526 \mathrm{~g} / \mathrm{day}(\mathrm{P}<0.001)$. Variation limits were comparable with similar studies for the same period of the year [33] and within technological aspects. As expected based on $A D G$, the final live gain and TLG were superior in yeast fed group reaching the weight of 80.72 grams while control group achieved $77.05 \mathrm{~g}$. FCR was 1.11 in yeast fed group and 1.25 in control group over the entire experimental period. Thus the productive effect of $S$. cerevisiae supplementation was higher than standard fodder.

\section{Hematological profile}

Significant differences were observed in hematological parameters for hemoglobin in yeast fed plot and higher variation limits $(P=0.0083, * *)$ (table 1$)$. Erythrocytes presented similar values $(P>0.05)$ but the same larger variation limits were recorded for yeasts fed group. Both erythrocytes and hemoglobin have direct role in oxygen pathways in the body [34, 35]. Nucleated erythrocytes as 


\begin{tabular}{|c|c|c|c|c|}
\hline Parameter & U.M. & Value & Control group & Yeast group \\
\hline \multirow{5}{*}{$\begin{array}{l}\text { Hemoglobin } \\
(\mathrm{Hb})\end{array}$} & \multirow{5}{*}{$(\mathrm{g} / \mathrm{dL})$} & $\mathrm{n}$ & 10 & 10 \\
\hline & & $\overline{\mathrm{X}} \pm \mathrm{s}_{\overline{\mathrm{x}}}$ & $10.00 \pm 0.1826$ & $10.72 \pm 0.1218^{* *}$ \\
\hline & & Min / Max & $9.4 / 11.0$ & $10.2 / 11.3$ \\
\hline & & St. deviation & 0.5774 & 0.3853 \\
\hline & & $P$ value & \multicolumn{2}{|c|}{0.0083} \\
\hline \multirow{5}{*}{$\begin{array}{l}\text { Erythrocyte } \\
\text { (Ery) }\end{array}$} & \multirow{5}{*}{$\left(\mathrm{mil} / \mathrm{mm}^{3}\right)$} & $\mathrm{n}$ & 10 & 10 \\
\hline & & $\overline{\mathrm{X}} \pm \mathrm{s} \overline{\mathrm{x}}$ & $2.598 \pm 0.0372$ & $2.610 \pm 0.0895$ \\
\hline & & $\operatorname{Min} / \operatorname{Max}$ & $2.46 / 2.75$ & $2.28 / 3.08$ \\
\hline & & St. deviation & 0.1176 & 0.2832 \\
\hline & & $P$ value & \multicolumn{2}{|c|}{0.7957} \\
\hline \multirow{5}{*}{$\begin{array}{l}\text { Hematocrit } \\
\text { (Hct) }\end{array}$} & \multirow{5}{*}{$(\%)$} & $\mathrm{n}$ & 10 & 10 \\
\hline & & $\overline{\mathrm{X}} \pm \mathrm{s} \overline{\mathrm{X}}$ & $40.8 \pm 1.42$ & $43.2 \pm 3.941$ \\
\hline & & $\operatorname{Min} / \operatorname{Max}$ & $36 / 48$ & $22 / 56$ \\
\hline & & St. deviation & 4.492 & 12.46 \\
\hline & & $P$ value & \multicolumn{2}{|c|}{0.2014} \\
\hline \multirow{5}{*}{$\mathrm{MCV}$} & \multirow{5}{*}{ (HTx 10/RBC) } & $\mathrm{n}$ & 10 & 10 \\
\hline & & $\overline{\mathrm{X}} \pm \mathrm{s} \overline{\mathrm{x}}$ & $157 \pm 4.634$ & $167.3 \pm 16.23$ \\
\hline & & $\operatorname{Min} / \operatorname{Max}$ & $144.5 / 174.6$ & $82.09 / 227.6$ \\
\hline & & St. deviation & 14.65 & 51.32 \\
\hline & & P value & \multicolumn{2}{|c|}{0.3312} \\
\hline
\end{tabular}

Table 1

HAEMATOLOGICAL PARAMETERS OF THE BLOOD IN RAINBOW TROUT (O. MYKISS) FOR CONTROL AND YEAST FED GROUPS

\begin{tabular}{|c|c|c|c|c|}
\hline Parameter & U.M. & Value & Control group & Yeast group \\
\hline \multirow{5}{*}{ GPx } & \multirow{5}{*}{$(\mathrm{U} / \mathrm{gHb})$} & $\mathrm{n}$ & 10 & 10 \\
\hline & & $\overline{\mathrm{X}} \pm \mathrm{s} \overline{\mathrm{x}}$ & $89.12 \pm 2.664$ & $90.32 \pm 2.392$ \\
\hline & & $\operatorname{Min} / \operatorname{Max}$ & $79.8 / 98.2$ & $80.9 / 101.5$ \\
\hline & & St. deviation & 8.424 & 7.565 \\
\hline & & $\mathrm{P}$ value & \multicolumn{2}{|c|}{0.7102} \\
\hline \multirow{5}{*}{ SOD } & \multirow{5}{*}{$(\mathrm{U} / \mathrm{gHb})$} & $\mathrm{N}$ & 10 & 10 \\
\hline & & $\bar{X} \pm s \bar{x}$ & $788.4 \pm 35.92$ & $759.6 \pm 14.56$ \\
\hline & & $\operatorname{Min} / \operatorname{Max}$ & $616.8 / 905$ & $700 / 814.3$ \\
\hline & & St. deviation & 113.6 & 46.05 \\
\hline & & P value & \multicolumn{2}{|c|}{0.3312} \\
\hline
\end{tabular}

fishes have may play a directrole in the immune response [36].

Higher values but in physiological limits presents benefits for cellular activities, implicitly for live body gain and feed conversion rate. Higher variation for erythrocytes in experimental plot $\left(2.61 \pm 0.134 \times 10^{6}, \mathrm{~V} \%=11.51\right.$ vs. $4.80 \%$ for control) may suggest a biological response to yeasts supplementation. Hematocrit was increased in yeast fed group and revealed higher variation of the mean value limits (SD = 12.46 vs. SD = 4.492 in control).

More hemoglobin into the red blood cells as a consequence of yeast supplementation but with nonsignificant differences for erythrocytes and hematocrit could be a response to higher cellular oxygen needs of the fish body due to more intense metabolism. No significant change in hematocrit and red blood cells values is to be expected within the two plots as no significant live gain over the entire period has been observed.

On the other hand, in fish especially, to which the erythrocytes have specific anatomy and physiology, higher volume, e.g. cytoplasm volume or nucleus size increases, is expected to have a direct correlation with erythrocytes count and the body size. Or erythrocytes value was similar in our experiment. In fundamental physiological theories, new insights suggest that Standard Metabolic Rate (SMR) is inversely related to erythrocyte and genome size in allopolyploid fish of the Cobitis taenia hybrid complex [37]. Considering in here the same genome configuration, the same breeding conditions and a normal physiologic metabolic growth for both groups, nutrition factor was the main factor for erythrocyte and their hemoglobin concentration variation in direct relation with specific metabolism of the administered nutrients.

Mean corpuscular volume (MCV) exhibit even higher mean variation limits $(S D=51.32$ in yeast fed vs. SD $=$ 14.65 in control) but no statistical differences were recorded. These values support the previous hematologic data and the direct correlation of red blood cells with live weight of the fish from both plots.

\section{Antioxidant indicators enzymes}

The two antioxidant indicators enzymes GPX and SOD presented similar but lower values in yeast fed plotfor SOD (table 2), which suggests a decrease of free radicals in these individuals and prevention of the oxidative damage. Antioxidant enzymes are largely known to be involved in ageing processes [38] but they very well could be used for metabolic studies as health indicators, mostly in fishes from natural area [39]. Our yeast fed plot benefit by lower oxidative damage, which further has been converted in live gain and higher feed conversion rate and we assume that yeasts also increased immunoboosting ability of the body. Apart of nutritional or probiotic role of the brewer yeasts, the high content of nucleic acid from yeasts, even in low doses, could interfere with the immune response, as shown to the same species in Tahmasebi-Kohyani \& al [40].

\section{Protein profile}

Protein profile (table 3 ) analysis revealed a very significant $(\mathrm{P}<0.001$, ***) response of yeast fed group regarding gamma globulins level. Significant changes ( $P$ 


\begin{tabular}{|c|c|c|c|c|}
\hline Parameter & U.M. & Value & Control group & Yeast group \\
\hline \multirow{5}{*}{$\begin{array}{c}\text { Urea } \\
\text { (BUN) }\end{array}$} & \multirow{5}{*}{$(\mathrm{mg} / \mathrm{dL})$} & $\mathrm{n}$ & 10 & 10 \\
\hline & & $\bar{X} \pm s \bar{x}$ & $13.28 \pm 0.3918$ & $12.22 \pm 0.4489$ \\
\hline & & $\operatorname{Min} / \operatorname{Max}$ & $11.8 / 15.4$ & $10.6 / 14.2$ \\
\hline & & St. deviation & 1.239 & 1.42 \\
\hline & & $P$ value & \multicolumn{2}{|c|}{0.2014} \\
\hline \multirow{5}{*}{$\begin{array}{c}\text { Total protein } \\
\text { (TP) }\end{array}$} & \multirow{5}{*}{$(\mathrm{g} / \mathrm{dL})$} & $\mathrm{n}$ & 10 & 10 \\
\hline & & $\overline{\mathrm{X}} \pm \mathrm{s} \overline{\mathrm{X}}$ & $3.442 \pm 0.1018$ & $3.74 \pm 0.09594^{* *}$ \\
\hline & & $\operatorname{Min} / \operatorname{Max}$ & $3 / 3.74$ & $3.2 / 4$ \\
\hline & & St. deviation & 0.3219 & 0.3034 \\
\hline & & $P$ value & & 098 \\
\hline \multirow{5}{*}{$\begin{array}{c}\text { Albumin } \\
\text { (ALB) }\end{array}$} & \multirow{5}{*}{$(\mathrm{g} / \mathrm{dL})$} & $\mathrm{n}$ & 10 & 10 \\
\hline & & $\overline{\mathrm{X}} \pm \mathrm{s} \overline{\mathrm{x}}$ & $1.984 \pm 0.03703$ & $1.998 \pm 0.04721$ \\
\hline & & $\operatorname{Min} / \operatorname{Max}$ & $1.8 / 2.1$ & $1.77 / 2.16$ \\
\hline & & St. deviation & 0.1171 & 0.1493 \\
\hline & & $P$ value & \multicolumn{2}{|c|}{0.6772} \\
\hline \multirow{5}{*}{ Gamma globulin } & \multirow{5}{*}{$(\mathrm{g} / \mathrm{dL})$} & $\mathrm{n}$ & 10 & 10 \\
\hline & & $\overline{\mathrm{X}} \pm \mathrm{s} \overline{\mathrm{x}}$ & $0.746 \pm 0.03538$ & $0.964 \pm 0.02464^{* * *}$ \\
\hline & & $\operatorname{Min} / \operatorname{Max}$ & $0.6 / 0.9$ & $0.82 / 1.03$ \\
\hline & & St. deviation & 0.1119 & 0.07792 \\
\hline & & P value & \multicolumn{2}{|c|}{0.0003} \\
\hline
\end{tabular}

Table 3

PROTEIN PROFILE OF THE BLOOD IN RAINBOW TROUT (O. MYKISS) FOR CONTROL AND YEAST FED GROUPS

differences; $n s-P>0.05$ - non-significant differences

$<0.01, * *)$ were also recorded for total proteins and similar values $(P>0.05)$ for urea and albumin. Increased levels of serum protein, albumin and globulins are considered to be associated with a stronger innate response in fishes [41].

In similar experiments on Labeo rohita fingerlings fed with yeast extract (YE), brewer's yeast (BY) and spirulina (SP) administered in some batches faced with Aeromonas hydrophila infection, 1\% YE gave higher globulins level and higher resistance supported by increased leucocyte count, nitro-blue tetrazolium (NBT) value and survival (\%) in both healthy and infected individuals [42]. Lower values for urea in our yeast fed groupmay be a sign of a more favorable nitrogen balance, considering that in most fishes' urea level mainly arises as a result of catabolism of excess purines through the process of uricolysis [43]. In spite of high levels of purines in brewer yeast [44] it seems that yeast fed individuals have been favored by certain factors in the easier metabolism of nitrogen.

\section{Carbohydrate profile}

Carbohydrate profile revealed similar but lower values for glucose and significantly lower values $\left(P<0.01,{ }^{* *}\right)$ for amylase in yeast fed group (table 4). Amylase is involved in carbohydrates digestion. Amylase activities vary between species and seem higher in herbivorous and omnivorous fishes than in carnivorous [45]. Serum level of our yeast fed group revealed similar values with other studies [46] but most importantly suggests a better valorization of carbohydrates from yeasts added fodder.

\section{Lipid profile}

Cholesterol and triglycerides values are similar in both plots $(P>0.05)$ (table5). Cholesterol level is higher in experimental plot and triglycerides are lower.

Higher level of lipase was present to experimental plot. Lipases have essential roles in the digestion, transport and processing of dietary lipids (i.e. triglycerides, fats, oils) and were mostly evaluated in feeding studies where the main topic was lipids. In rainbow trout replacing dietary fish oil by vegetable oils has little effect on lipogenesis, lipidtransport and tissue lipid uptake [47].

In our study there is little added quantitatively of lipids in the experimental diet, but probiotic action of the yeasts has to be expected to favor lipid metabolism and not only. Lower triglycerides in experimental fish blood are theoretically an indicator of a better carbohydrate metabolism but they have to be broken down to be further utilized by the organism. Or for that lipase has an important role and in yeast fed individuals the levels were higher. Overall, the addition of yeast favored lipid and energy metabolism.

\section{Enzymatic profile}

Enzymatic profile of the bloodgenerally falls within normal physiological limits of the species [48]. Two enzymes show statistically significant differences between the two groups (table 6), which are ALP $(P<0.01, * *)$ and CPK $(\mathrm{P}<0.001, * * *)$.

\begin{tabular}{|c|c|c|c|c|}
\hline Parameter & U.M. & Value & Control group & Yeast group \\
\hline \multirow{5}{*}{$\begin{array}{l}\text { Glucose } \\
(\mathrm{GLU})\end{array}$} & \multirow{5}{*}{$(\mathrm{mg} / \mathrm{dL})$} & $\mathrm{n}$ & 10 & 10 \\
\hline & & $\overline{\mathrm{X}} \pm \mathrm{s} \overline{\mathrm{x}}$ & $64.48 \pm 1.836$ & $65.72 \pm 1.163$ \\
\hline & & $\operatorname{Min} / \operatorname{Max}$ & $58.1 / 71.6$ & $59.3 / 69.1$ \\
\hline & & St. deviation & 5.807 & 3.678 \\
\hline & & $\mathrm{P}$ value & \multicolumn{2}{|c|}{0.9407} \\
\hline \multirow{5}{*}{$\begin{array}{l}\text { Amylase } \\
\text { (AMS) }\end{array}$} & \multirow{5}{*}{$(\mathrm{U} / \mathrm{L})$} & $\mathrm{n}$ & 10 & 10 \\
\hline & & $\overline{\mathrm{X}} \pm \mathrm{s}_{\overline{\mathrm{x}}}$ & $148.1 \pm 8.883$ & $112.6 \pm 6.758^{* *}$ \\
\hline & & $\operatorname{Min} / \operatorname{Max}$ & $114 / 180.6$ & $90 / 150$ \\
\hline & & St. deviation & 28.09 & 21.37 \\
\hline & & P value & \multicolumn{2}{|c|}{0.0014} \\
\hline
\end{tabular}

Table 4

CARBOHYDRATE PROFILE OF THE BLOOD IN RAINBOW TROUT (O. MYKISS) FOR CONTROL AND YEAST FED GROUPS

\footnotetext{
** $\mathrm{P}<0.01$ - distinctively significant differences;
} $\mathrm{ns}-\mathrm{P}>0.05$ - non-significant differences 


\begin{tabular}{|c|c|c|c|c|}
\hline Parameter & U.M. & Value & Control group & Yeast group \\
\hline \multirow{5}{*}{ Cholesterol (CHOL) } & \multirow{5}{*}{$(\mathrm{mg} / \mathrm{dL})$} & $\mathrm{N}$ & 10 & 10 \\
\hline & & $\overline{\mathrm{X}} \pm \mathrm{s} \overline{\mathrm{x}}$ & $194.3 \pm 3.328$ & $200.3 \pm 3.177$ \\
\hline & & Min / Max & $180.9 / 210.2$ & $189.2 / 214$ \\
\hline & & St. deviation & 10.53 & 10.05 \\
\hline & & $\mathrm{P}$ value & \multicolumn{2}{|c|}{0.2014} \\
\hline \multirow{5}{*}{ Triglycerides (TG) } & \multirow{5}{*}{$(\mathrm{mg} / \mathrm{dL})$} & $\mathrm{n}$ & 10 & 10 \\
\hline & & $\overline{\mathrm{X}} \pm \mathrm{s} \overline{\mathrm{x}}$ & $372.2 \pm 40.88$ & $324.2 \pm 8.404$ \\
\hline & & $\operatorname{Min} / \operatorname{Max}$ & $270.4 / 601.5$ & $290.1 / 353$ \\
\hline & & St. deviation & 129.3 & 26.57 \\
\hline & & $P$ value & \multicolumn{2}{|c|}{0.9407} \\
\hline \multirow{5}{*}{$\begin{array}{l}\text { Lipase } \\
\text { (IIP) }\end{array}$} & \multirow{5}{*}{$(\mathrm{U} / \mathrm{L})$} & $\mathrm{n}$ & 10 & 10 \\
\hline & & $\overline{\mathrm{X}} \pm \mathrm{s}_{\overline{\mathrm{x}}}$ & $18.42 \pm 2.184$ & $19.86 \pm 0.4665$ \\
\hline & & $\operatorname{Min} / \operatorname{Max}$ & $7.2 / 27$ & $18.2 / 22.4$ \\
\hline & & St. deviation & 6.905 & 1.475 \\
\hline & & P value & & 07 \\
\hline
\end{tabular}

Table 5

LIPID PROFILE OF THE BLOOD IN RAINBOW TROUT (O. MYKISS) FOR CONTROL AND YEAST FED GROUPS

ns - $\mathrm{P}>0.05$ - non-significant difference

\begin{tabular}{|c|c|c|c|c|}
\hline Parameter & U.M. & Value & Control group & Yeast group \\
\hline \multirow{5}{*}{ Creatinine (CREAT) } & \multirow{5}{*}{$(\mathrm{mg} / \mathrm{dL})$} & $\mathrm{N}$ & 10 & 10 \\
\hline & & $\overline{\mathrm{X}} \pm \mathrm{s} \overline{\mathrm{x}}$ & $0.544 \pm 0.03284$ & $0.54 \pm 0.03018$ \\
\hline & & $\operatorname{Min} / \operatorname{Max}$ & $0.39 / 0.68$ & $0.42 / 0.69$ \\
\hline & & St. deviation & 0.1038 & 0.09545 \\
\hline & & $P$ value & \multicolumn{2}{|c|}{$>0.9999$} \\
\hline \multirow{5}{*}{$\begin{array}{c}\text { Alanine aminotransferase } \\
\text { (ALAT) }\end{array}$} & \multirow{5}{*}{$(\mathrm{U} / \mathrm{L})$} & $\mathrm{n}$ & 10 & 10 \\
\hline & & $\bar{X} \pm s \bar{x}$ & $15.2 \pm 1.447$ & $12.56 \pm 0.9176$ \\
\hline & & $\operatorname{Min} / \operatorname{Max}$ & $9.8 / 20.5$ & $8.9 / 16.2$ \\
\hline & & St. deviation & 4.576 & 2.902 \\
\hline & & $P$ value & \multicolumn{2}{|c|}{0.1121} \\
\hline \multirow{5}{*}{$\begin{array}{c}\text { Aspartate aminotransferase } \\
\text { (ASAT) }\end{array}$} & \multirow{5}{*}{$(\mathrm{U} / \mathrm{L})$} & $\mathrm{n}$ & 10 & 10 \\
\hline & & $\overline{\mathrm{X}} \pm \mathrm{s} \overline{\mathrm{x}}$ & $235.2 \pm 20.01$ & $239.4 \pm 14.56$ \\
\hline & & $\operatorname{Min} / \operatorname{Max}$ & $172 / 315$ & $190 / 302$ \\
\hline & & St. deviation & 63.28 & 46.04 \\
\hline & & $P$ value & \multicolumn{2}{|c|}{0.5027} \\
\hline \multirow{5}{*}{$\begin{array}{l}\text { Glutamyl transferase } \\
\text { (GGT) }\end{array}$} & \multirow{5}{*}{$(\mathrm{U} / \mathrm{L})$} & $\mathrm{n}$ & 10 & 10 \\
\hline & & $\overline{\mathrm{X}} \pm \mathrm{s} \overline{\mathrm{X}}$ & $6.54 \pm 0.8437$ & $8.26 \pm 0.4086$ \\
\hline & & $\operatorname{Min} / \operatorname{Max}$ & $2 / 9.3$ & $6.4 / 9.8$ \\
\hline & & St. deviation & 2.668 & 1.292 \\
\hline & & $\mathrm{P}$ value & \multicolumn{2}{|c|}{0.2014} \\
\hline \multirow{5}{*}{ Alkaline phosphatase (ALP) } & \multirow{5}{*}{$(\mathrm{U} / \mathrm{L})$} & $\mathrm{n}$ & 10 & 10 \\
\hline & & $\overline{\mathrm{X}} \pm \mathrm{s} \overline{\mathrm{x}}$ & $132.6 \pm 9.937$ & $178.6 \pm 12.36^{* *}$ \\
\hline & & $\operatorname{Min} / \operatorname{Max}$ & $94 / 170$ & $109.8 / 216$ \\
\hline & & St. deviation & 31.42 & 39.1 \\
\hline & & P value & \multicolumn{2}{|c|}{0.0032} \\
\hline \multirow{5}{*}{$\begin{array}{l}\text { Lactate dehydrogenase } \\
\text { (LDH) }\end{array}$} & \multirow{5}{*}{$(\mathrm{U} / \mathrm{L})$} & $\mathrm{n}$ & 10 & 10 \\
\hline & & $\overline{\mathrm{X}} \pm \mathrm{s} \overline{\mathrm{x}}$ & $786 \pm 56.24$ & $676.4 \pm 101.9$ \\
\hline & & $\operatorname{Min} / \operatorname{Max}$ & $514 / 1000$ & $81.6 / 902$ \\
\hline & & St. deviation & 177.8 & 322.3 \\
\hline & & P value & \multicolumn{2}{|c|}{0.5027} \\
\hline \multirow{5}{*}{$\begin{array}{l}\text { Creatinine phosphokinase } \\
\text { (CPK) }\end{array}$} & \multirow{5}{*}{$(\mathrm{U} / \mathrm{L})$} & $\mathrm{n}$ & 10 & 10 \\
\hline & & $\overline{\mathrm{X}} \pm \mathrm{s}_{\overline{\mathrm{X}}}$ & $90.9 \pm 3.177$ & $69.68 \pm 2.631 * * *$ \\
\hline & & $\operatorname{Min} / \operatorname{Max}$ & $74 / 100.3$ & $60.4 / 80$ \\
\hline & & St. deviation & 10.05 & 8.319 \\
\hline & & P value & & $\overline{008}$ \\
\hline
\end{tabular}

ENZYMATIC PROFILE OF THE BLOOD IN RAINBOW TROUT (O. MYKISS) FOR CONTROL AND YEAST FED GROUPS

$-\mathrm{P}<0.001$ - very significant differences; $* *$ - $\mathrm{P}<0.01$ - distinctiv
$n s-\mathrm{P}=0.05$ - non-significant differences

ALP level is within physiological limits to both groups. This enzyme plays an integral role in metabolism within the liver and development within the skeleton and significant higher levels in yeast fed individuals could suggest liver disorders or osteomalacia. But not the case in here as long physiological parameters level is within normal ranges. CPK level is significantly lower in yeast fed groupsand low values as compared with reference values. This low level could be an indicator for good function of this enzyme as is for the others analyzed in here.

\section{Mineral profile}

Mineral profile revealed similar values $(P>0.05)$ (table 7) for both batches and for all parameters ( $\mathrm{Ca}, \mathrm{Fe}, \mathrm{P}, \mathrm{Na}, \mathrm{K}$ ) and was within physiological limits [46]. Although several minerals have been associated with higher productive parameters or physiological status in 0 . mykiss by which probably the mostimportant being zinc [49], basic mineral profile offers indices about health status. No significant change within physiological limits to our individuals from 


\begin{tabular}{|c|c|c|c|c|}
\hline Parameter & UM. & Value & Control group & Yeast group \\
\hline \multirow{5}{*}{$\underset{\left(\mathrm{Ca}^{2+}\right)}{\text { Calcium }}$} & \multirow{5}{*}{$(\mathrm{mg} / \mathrm{dL})$} & $\mathrm{n}$ & 10 & 10 \\
\hline & & $\overline{\mathrm{X}} \pm \mathrm{s} \overline{\mathrm{x}}$ & $12.3 \pm 0.5914$ & $11.58 \pm 0.2744$ \\
\hline & & $\mathrm{Min} / \mathrm{Max}$ & $10 / 15.1$ & $10.7 / 12.8$ \\
\hline & & St. deviation & 1.87 & 0.8677 \\
\hline & & $P$ value & \multicolumn{2}{|c|}{0.3898} \\
\hline \multirow{5}{*}{$\begin{array}{c}\text { Iron } \\
\left(\mathrm{Fe}^{3+}\right)\end{array}$} & \multirow{5}{*}{$(\mu \mathrm{g} / \mathrm{dL})$} & $\mathrm{n}$ & 10 & 10 \\
\hline & & $\overline{\mathrm{X}} \pm \mathrm{s} \overline{\mathrm{x}}$ & $205.7 \pm 12.11$ & $197.8 \pm 16.06$ \\
\hline & & $\operatorname{Min} / \operatorname{Max}$ & $160 / 270.9$ & $119 / 270$ \\
\hline & & St. deviation & 38.29 & 50.79 \\
\hline & & $P$ value & \multicolumn{2}{|c|}{0.9407} \\
\hline \multirow{5}{*}{ Phosphorus (P) } & \multirow{5}{*}{$(\mathrm{mg} / \mathrm{dL})$} & $\mathrm{n}$ & 10 & 10 \\
\hline & & $\overline{\mathrm{X}} \pm \mathrm{s} \overline{\mathrm{x}}$ & $20.18 \pm 0.4919$ & $20.5 \pm 0.2836$ \\
\hline & & $\operatorname{Min} / \operatorname{Max}$ & $18.4 / 22.8$ & $19.2 / 21.3$ \\
\hline & & St. deviation & 1.555 & 0.8969 \\
\hline & & $P$ value & & 53 \\
\hline \multirow{5}{*}{$\begin{array}{l}\text { Sodium } \\
\text { (Na) }\end{array}$} & \multirow{5}{*}{$(\mathrm{mmol} / \mathrm{L})$} & $\mathrm{n}$ & 10 & 10 \\
\hline & & $\overline{\mathrm{X}} \pm \mathrm{s}_{\overline{\mathrm{x}}}$ & $150 \pm 3.645$ & $158.9 \pm 2.666$ \\
\hline & & $\operatorname{Min} / \operatorname{Max}$ & $130.1 / 160$ & $150.9 / 168.7$ \\
\hline & & St. deviation & 11.53 & 8.432 \\
\hline & & $\mathrm{P}$ value & \multicolumn{2}{|c|}{0.1024} \\
\hline \multirow{5}{*}{$\begin{array}{l}\text { Potassium } \\
(\mathrm{K})\end{array}$} & \multirow{5}{*}{$(\mathrm{mmol} / \mathrm{L})$} & $\mathrm{n}$ & 10 & 10 \\
\hline & & $\overline{\mathrm{X}} \pm \mathrm{s} \overline{\mathrm{x}}$ & $4.28 \pm 0.3262$ & $3.92 \pm 0.04422$ \\
\hline & & $\mathrm{Min} / \mathrm{Max}$ & $3.2 / 6.1$ & $3.7 / 4.1$ \\
\hline & & St. deviation & 1.032 & 0.1398 \\
\hline & & P value & \multicolumn{2}{|c|}{0.5651} \\
\hline
\end{tabular}

Table 7

MINERAL PROFILE OF THE BLOOD IN RAINBOW TROUT (O. MYKISS) FOR CONTROL AND YEAST FED GROUPS both batches is a mark of a good health and mineral metabolism.

\section{Conclusions}

Brewer yeast supplemented fodder of $1.5 \%$ in salmon trout bred in classic system conducted to higher ADG, TLG and FCR. Antioxidant activity measured by blood biochemical analyzes revealed an increased immunoboosting ability of the body. Proteinprofile suggests a stronger innate response in fishes and e better valorization of nitrogen sources. Lipid profile could suggest a better carbohydrate metabolism, while enzymatic activity was within normal but lower values of physiological ranges, as for minerals is. Overall, $1.5 \%$ addition of brewer yeasts in rainbow trout nutrition has beneficial effects, both as probiotic and nutritional added value.

\section{References}

1.CHO, C.Y., COWEY, C.B., Rainbow trout, Oncorhynchus mykiss, In R.P. Wilson, Ed. Handbook of nutrient requirements of finfish, Boca Raton, CRC Press, 1991, p. 131.

2.NATIONAL RESEARCH COUNCIL, Nutrient Requirements of Fish, Washington, DC: The National Academies Press, 1993, p. 16.

3.HALVER, E., HARDY, R.W., Editors In Fish nutrition, 3, Academic Press, Harcourt Place, 32 Jamestown Road, London, NW 1 7BY, UK, 2002, p. 7.

4. HARDY, R.W., Rainbow trout, Oncorhynchus mykiss. In C.D. Webster $\&$ C.E. Lim, eds. Nutrient requirements and feeding of finfish for aquaculture, CABI Publishing, New York, 2002, p. 184.

5.TACON, A.G.J., METIAN, M., Aquaculture, 285, 2008, p. 146.

6.NAYLOR, R.L., HARDY, R.W., BUREAU, D.P., CHIU, A., ELLIOTT, M., FARRELL, A.P.,FORSTER, I., DELBERT, M., GOLDBURG, R.J., KATHELINE, H., PETER, D., Proc. Natl. Acad. Sci.,106, 2009, p. 15103. 7.OLSEN, R.L., HASAN, M.R., Trends Food Sci. Tech., 27, no. 2, 2012, p. 120.

8.BOYD, C.E., TUCKER, C., MCNEVIN, A., BOSTICK, K., CLAY, J., Reviews in Fisheries Science, 15, 2007, p. 327.

9.0LIVA-TELES, A., GONC'ALVES, P., Aquaculture, 202, 2001, p. 269.
10.MUZINIC, L.A., THOMPSON, K.R., MORRIS, A., WEBSTER, C.D., ROUSE, D.B., MANOMAITIS, L., Aquaculture, 230, 2004, p. 359.

11.FERREIRA, I.M.P.L.V.O., PINHO, O., VIEIRA, E., TAVARELA, J.G., Trends Food Sci. Tech., 21, 2010, p. 77.

12.0VERLAND, M., SKREDE, A., J. Sci. Food Agr., 97, 2017, p. 733.

13.CHENG, Z.J ., HARDY, R.H., Aquaculture, 35, 2004, p. 1.

14.FARCASANU, I.C., OPREA, E., PARASCHIVESCU, C., RUTA, L., AVRAMESCU, S., Rev. Chim. (Bucharest), 59, no. 9, 2008, p. 1041.

15.SALNUR, S., GULTEPE, N., HOSSU, B., J. Anim. Vet. Adv., 8, 2009, p. 2557.

16.PAVASOVIC, A., ANDERSON, A.J ., MATHER, P.B., RICHARDSON, N.A., Aquaculture, 272, 2007, p. 564.

17.OVERLAND, M., KARLSSON, A., MYDLAND, L.T., ROMARHEIM, O.H., SKREDE, A., Aquaculture, 402-403, 2013, p. 1.

18.0VERLAND, M., SKREDE, A., J. Sci. Food Agr., 97, 2017, p. 733.

19.HEIDARIEH, M., MIRVAGHEFI, A.R., AKBARI, M., SHEIKHZADEH, N., KAMYABI-MOGHADDAM, Z., ASKARI, H., SHAHBAZFAR, A.A., Aquacult. Nutr., 19, 2013, p. 343.

20.GONÇALVES, A.T., GALLARDO-ESCARATE, C., J. Appl. Microbiol., 122, 2017, p. 1333.

21.GAYLORD, T.G., SEALEY, W.M, BARROWA, F.T, MYRICK, C.A., FORNSHELL, G., AquacultNutr, 2017, p. 10.

22.ZHANG, J.X., GUO, L.Y., FENG, L., JIANG, W.D., KUANG, S.Y., LIU, Y., HU, K., JIANG, J., LI, S.H., TANG, L., ZHOU, X.Q., PLOS ONE, 8, no. 3, 2013, p. 1.

23.0STASZEWSKA, T., DABROWSKI, K., PALACIOS, M.E., OLEJ NICZAK, M., WIECZOREK, M., Aquaculture, 245, 2005, p. 273.

24.GOMES, E.F., REMA, P., KAUSHIK, S.) ., Aquaculture, 130, no. 2-3, 1995, p. 177.

25.KAUSHIK, S.J ., CRAVEDI, J.P., LALLES, J.P., SUMPTER, J ., FAUCONNEAU, B., LAROCHE, M., Aquaculture, 133, 1995, p. 257. 26.CARTER, C.G., HAULER, R.C., Aquaculture, 185, no. 3-4, 2000, p. 299.

27.BELL, J.G., STRACHAN, F., ROY, W.J., MATTHEW, C., MCDONALD, P. BARROWS, F.T., SPRAGUE, M., Aquacult. Nutr., 22, 2016, p. 326. 28.GATESOUPE, F.J., Aquaculture, 267, no. 1-4, 2007, p. 20.

29.SEALEY, W.M., O'NEILL, T.J., PEACH, J.T., GAYLORD, T.G., BARROWS, F.T., BLOCK, S.S., J. World Aquacult. Soc., 46, 2015, p. 434. 
30.HAUPTMAN, B.S., BARROWS, F.T., BLOCK, S.S., GAYLORD, T.G., PATERSON, J.A., RAW LES, S.D., SEALEY, W.M., Aquaculture, 432, 2014, p. 7.

31.J AVED, M., AHMAD, M.D.I., USMANI, N., AHMAD, M., Scientific Reports, 7, 2017, p. 1.

32.GHERGARIU, S., LASZLO, K., POP, A., SPANU, M., Manual de laborator clinic veterinar, Ed. All, Timisoara, 1999, p. 38.

33.IHUT, A., MIRESAN, V., RADUCU, C., COCAN, D., CONSTANTINESCU, R., Bulletin UASVM Animal Science and Biotechnologies, 71, no. 1, 2014, p. 9.

34.NIKINMAA, M., SALAMA, A., Oxygen transport in fish. In: Perry, S.F., Tufts, B.L. (Eds.), Fish Respiration, Academic Press, New York, 1998, p. 141.

35.NIKINMAA, M., Comparative Biochemistry and Physiology Part A, 133, 2002, p. 1.

36.MORERA, D., MACKENZIE, S.A., Vet Res, 42, 2011, p. 89.

37.MACIAK, S., JANKO, K., KOTUSZ, J., CHOLEVA, L., BORON, A., JUCHNO, D., KUJ AWA, R., KOZfOWSKI, J., KONARZEWSKI, M., Funct Ecol, 25, 2011, p. 1072.

38.EDREY, Y.H., SALMON, A.B., Free Radic Biol Med, 71, 2014, p. 368.
39.DUMITRU, G., TODIRASCU CIORNEA, E., HRITCU, L., SANDU, I.G., Rev. Chim. (Bucharest), 69, no. 5, 2018, p. 1194.

40.TAHMASEBI-KOHYANI, A., KEYVANSHOKOOH, S., NEMATOLLAHI, A., MAHMOUDI, N., PASHA-ZANOOSI, H., Fish Shellfish Immun, 30, 2011, p. 189.

41.J HA, A.K., PAL, A.K., SAHU, N.P., KUMAR, S., MUKHERJ EE, S.C., Fish Shellfish Immun, 23, 2007, p. 917.

42.ANDREWS, S.R., SAHU, N.P., PAL, A.K., MUKHEREJ EE, S.C., KUMAR, S., Res Vet Sci, 91, 2011, p. 103.

43.WILKIE, M.P., J ournal of Experimental Zoology, 293, 2002, p. 284. 44.KANEKO, K., AOYAGI, Y., FUKUUCHI, T., INAZAWA, K., YAMAOKA, N., Biol Pharm Bull, 37, no. 5, 2014, p. 709.

45.HIDALGO, M.C., UREA, E., SANZ, A., Aquaculture, 170, 1999, p. 267. 46.IHUT, A., CRADUCU, C., COCAN, D., LATIU, C., UIUIU, P., MIRESAN, V., Bulletin UASVM Animal Science and Biotechnologies, 75, no. 1, 2018, p. 46.

47.RICHARD, N., KAUSHIK, S., LARROQUET, L., PANSERAT, S., CORRAZE, G., British J ournal of Nutrition, 96, no. 2, 2006, p. 299. 48.MANERA, M., BRITTI, D., J Fish Biol, 69, 2006, p. 1427.

49.KUCUKBAY, Z., YAZLAK, H., SAHIN, N., TUZCU, M., CAKMAK, M.N., GURDOGAN, F., JUTURU, V., SAHIN, K., Aquaculture, 257, 2006, p. 465.

$\overline{\text { Manuscript received: } 14.08 .2019}$ 